\title{
The Effect of Urea Infusion on the Urinary \\ Concentrating Mechanism in Protein-Depleted Rats
}

\author{
J. Phillip Pennell, Veeraf Sanjana, Norman R. Frey, and \\ Rex L. Jamison \\ From the Division of Nephrology, Department of Medicine, Stanford \\ University School of Medicine, Stanford, California 94305
}

A B S T R A C T To explore the role of urea in the urinary concentrating mechanism, the contents of vasa recta, Henle's descending limbs and collecting ducts were sampled by micropuncture of the renal papilla before and after infusion of urea in 10 protein-depleted rats. Eight protein-depleted rats not given urea were similarly studied as a control group. After urea administration, osmolality and the concentrations of urea and nonurea solute of urine from both exposed and contralateral kidney increased significantly. The osmolality and urea concentration of fluid from the end of Henle's descending limb and vasa recta plasma and the tubule fluid-to-plasma inulin ratio in the end-descending limb all increased significantly after urea infusion. We interpret these observations to indicate that urea enhances urinary concentration by increasing the abstraction of water from the juxtamedullary nephron (presumably the descending limb), in agreement with the prediction of recent passive models of the urinary concentrating mechanism. However, the concentration of urea in fluid from the descending limb after urea infusion was high $(261 \pm 31 \mathrm{mM})$ and the difference in sodium concentration between descending limb fluid and vasa recta was small and statistically insignificant.

\section{INTRODUCTION}

Animals deprived of dietary protein exhibit an impaired ability to concentrate their urine, which is reversed by

Portions of this work were presented to the American Society of Nephrology; Pennell, J. Phillip, Norman R. Frey, and Rex L. Jamison. 1973. The effect of infusing urea to protein-depleted rats on composition of vasa recta plasma and fluid in Henle's loop and collecting duct. Proceedings of the 6th Meeting of the American Society of Nephrology. 82. (Abstr.).

Dr. Jamison is a Markle Scholar in academic medicine.

Received 8 April 1974 and in revised form 26 July 1974. administration of urea (1-7). Despite numerous investigations (8), the mechanism by which urea enhances urinary osmolality remains unclear.

Recent theoretical models by Stephenson (9) and Kokko and Rector (10) have suggested a new role for urea in the inner medullary concentrating mechanism. In Stephenson's model, urea supplied to the medullary interstitium by the collecting tubule induces osmotic withdrawal of water from the descending limb which concentrates $\mathrm{NaCl}$ within the descending limb and dilutes $\mathrm{NaCl}$ in the medullary interstitium, depressing its $\mathrm{NaCl}$ concentration relative to that in Henle's loop. A favorable gradient is thus established for outward $\mathrm{NaCl}$ diffusion from the water-impermeable thin ascending limb ("passive mode"). Stephenson's model incorporates a second mode of achieving hypotonicity of fluid within the thin ascending limb : by active transport of solute $\left(\mathrm{Na}^{+}\right)$from the thin ascending limb ("active mode"). The active and passive modes may operate alone or together (9).

Kokko $(11,12)$ has shown that the isolated perfused descending limb is very permeable to water and has a reflection coefficient for $\mathrm{NaCl}$ and urea near unity. Based on these findings, Kokko and Rector (10) proposed that fluid in the descending limb becomes concentrated almost exclusively by water extraction, owing to the high concentration of urea in the medullary interstitium, and that medullary hypertonicity is generated in a manner similar to the passive mode of Stephenson's model.

The purpose of this study was to examine the changes in composition of collecting duct and loop fluid and vasa recta plasma associated with the enhanced urinary osmolality caused by the infusion of urea into protein-depleted rats, and to determine whether the changes conform to the recent models of the concentrating mechanism. If the source of energy for inner medullary hypertonicity is provided exclusively by a concentrated solution of urea 
entering the inner medullary interstitium from the collecting tubules (passive mode), one would expect the following findings associated with the enhancement of urinary osmolality caused by the infusion of urea to protein-depleted rats: $(a)$ increase in osmolality of fluid in Henle's loop and of plasma in vasa recta; $(b)$ increase in tubule fluid-to-plasma $(\mathrm{TF} / \mathrm{P})^{1}$ inulin ratio at the end of Henle's descending limb reflecting an increase in water abstraction from that segment; $(c)$ increase in the concentration of urea in collecting tubule fluid and vasa recta plasma ${ }^{2}$ which exceeds the increase in concentration of urea in loop fluid; $(d)$ increase in concentration of sodium in fluid at the end of Henle's descending limb which exceeds the increase in concentration of sodium in vasa recta plasma.

\section{METHODS}

Male Sprague-Dawley weanling rats ranging from 50 to $68 \mathrm{~g}$ in weight were fed a low protein diet for at least 3 wk (Nutritional Biochemicals Corp., Cleveland, Ohio) and allowed free access to water before study. This diet is a "low $8 \%$ protein" diet containing $8.0 \%$ casein, $78.0 \%$ starch, $10.0 \%$ vegetable oil, and $4.0 \%$ salt mixture no. 2 U.S.P. (200 meq $\mathrm{NaCl}$ per $100 \mathrm{~g}$ food), plus complete vitamin supplements. The rats were prepared for micropuncture of the left renal papilla, as previously described $(13,14)$, except that no infusion was given during surgery. Urine from the right kidney was collected with a bladder catheter.

The rats were divided into two groups. 10 rats (group I) were studied initially during infusion at $0.03 \mathrm{ml} / \mathrm{min}$ of $0.9 \%$ saline containing $1.8 \mathrm{mU} / \mathrm{ml}$ antidiuretic hormone (ADH) (Pitressin, Parke, Davis \& Co., Detroit, Mich.) and sufficient inulin to achieve plasma levels of 80-100 $\mathrm{mg} / 100 \mathrm{ml}$. They were restudied in a second period $80 \mathrm{~min}$ after beginning a saline infusion containing $1.8 \mathrm{mU} / \mathrm{ml}$ $\mathrm{ADH}$ and $200 \mathrm{mM}$ urea. A second group of rats was studied similarly except that in the second period urea was not added to the isotonic saline (plus ADH) infusion (group II).

During each period, fluid was collected from the tip of papillary collecting ducts, and a loop of Henle near the hairpin turn, as described before $(13,14)$, and from an adjacent ascending vas rectum. Vasa recta blood was collected with a micropuncture pipet having a tip diameter of $8-9 \mu \mathrm{m}$. After puncture of a vas rectum, a small column of Kel-F oil (Kel-F, 3M Company, St. Paul, Minn.) was injected to detect inadvertent entry of the pipet into a loop or collecting duct and to confirm puncture of an ascending vas rectum. If a tubule was entered during puncture or if the stream of erythrocytes entering the pipet was not continuous, the sample was discarded. Plasma samples were obtained to bracket each collection period.

The procedures used to handle tubule fluid have been described before (15). Vasa recta blood samples were handled in the following manner: Immediately after col-

\footnotetext{
${ }^{1}$ Abbreviations used in this paper: $\mathrm{ADH}$, antidiuretic hormone; $\mathrm{TF} / \mathrm{P}$, tubule fluid-to-plasma.

${ }^{2}$ It is assumed that for small solutes like sodium, chloride, and urea the contents of vasa recta and medullary interstitium are in equilibrium. A similar assumption was made by Stephenson (9) and by Kokko and Rector (10).
}

lection, the sample of vasa recta blood was discharged from the pipet onto the bottom of a glass petri dish filled witl mineral oil and then was aspirated into a glass microcapillary tube with oil on either side of the sample. After one end was sealed with an oxygen microtorch, the microcapillary tube was placed in a larger microhematocrit tube and centrifuged for $10 \mathrm{~min}$. The microcapillary tube containing the sample was removed, placed under oil, and the end containing the cells broken off with tweezers so that the plasma could be transferred to an oil-filled plastic trough designed for mounting on a microtransfer apparatus. Thereafter, the sample was handled in the same manner as tubule fluid samples.

Fluid from loops and collecting ducts, vasa recta plasma, urine, and systemic plasma were analyzed for osmolality, sodium, potassium, inulin, and urea by methods previously described $(15,16)$.

At the end of the experiment, samples of arterial blood were obtained from seven rats (four urea infused, three control rats) for measurement of total serum protein concentration $(17)^{3}$ (mean $\left.=2.6 \pm 0.3 \mathrm{~g} / 100 \mathrm{ml}\right)$.

Urea concentration in vasa recta plasma was corrected for plasma water, assuming protein concentration of vasa recta plasma of $5 \mathrm{~g} / 100 \mathrm{ml}$. The concentration of sodium was not corrected for plasma water in the vasa recta since the effect of the Gibbs-Donnan rule would contribute a nearly equal but opposite correction.

Data presented are the mean $\pm \mathrm{SE}$ derived from the data for each rat. Differences between urea-infused and control rats were analyzed statistically with the Student's $t$ test; differences between the first and second periods within each group were analyzed with the paired $t$ test (18).

\section{RESULTS}

The growth rate of protein-depleted rats was markedly reduced: daily weight gain was less than $1 \mathrm{~g}$, whereas weanling rats fed a normal diet gain about $5 \mathrm{~g}$ per day (unpublished observations). Arterial blood and plasma data are presented in Table I. The mean plasma urea concentration of the protein-depleted rats $(2.9 \pm 0.2 \mathrm{mM})$ was less than half that of rats of equivalent weight-fed normal diets $(6.5 \pm 0.3 \mathrm{mM})$ (16). After infusion of urea, plasma urea increased substantially from $3.1 \pm 0.2$ $\mathrm{mM}$ to $14.3 \pm 0.9 \mathrm{mM}$, while plasma osmolality rose slightly but not significantly.

Whole kidney function (right kidney) (Table II). The rate of urinary flow did not increase significantly in the second period in the urea-infused rats but did in the control rats. The mean glomerular filtration rate did not change significantly in either group. The increase in urinary osmolality after urea infusion was significantly greater than that observed in the control group. Urinary urea concentration increased significantly only in the urea-infused group, but the urinary concentration of nonurea solute increased significantly in both groups. Fractional excretion of total solute, water, and sodium was similar in the two groups.

\footnotetext{
${ }^{3} \mathrm{We}$ are indebted to the Stanford University Hospital Clinical Chemistry Laboratory and Dr. Paul Wolfe for performing this determination.
} 
TABLE I

Arterial Blood and Plasma

\begin{tabular}{|c|c|c|c|c|c|c|c|}
\hline & \multirow{2}{*}{\multicolumn{3}{|c|}{$\begin{array}{c}\text { Group I, urea infusion }(n=10) \\
\text { Body wt } 63 \pm 2 \mathrm{~g}\end{array}$}} & \multirow[b]{3}{*}{$P \ddagger$} & \multirow{2}{*}{\multicolumn{3}{|c|}{$\begin{array}{c}\text { Group II, control }(n=8) \\
\text { Body wt } 62 \pm 2 \mathrm{~g}\end{array}$}} \\
\hline & & & & & & & \\
\hline & $\begin{array}{l}\text { First } \\
\text { period }\end{array}$ & $P^{*}$ & $\begin{array}{l}\text { Second } \\
\text { period }\end{array}$ & & $\begin{array}{l}\text { First } \\
\text { period }\end{array}$ & $P^{*}$ & $\begin{array}{l}\text { Second } \\
\text { period }\end{array}$ \\
\hline $\begin{array}{l}\text { Blood pressure, } \\
\quad m m ~ H g\end{array}$ & $114 \pm 3$ & $<0.05$ & $106 \pm 3$ & NS & $111 \pm 5$ & $<0.025$ & $99 \pm 5$ \\
\hline Hematocrit, $\%$ & $41 \pm 1$ & NS & $39 \pm 1$ & NS & $42 \pm 1$ & NS & $41 \pm 1$ \\
\hline $\begin{array}{l}\text { Osmolality, } \\
\quad \text { mosmols } / \mathrm{kg} \mathrm{H}_{2} \mathrm{O}\end{array}$ & $311 \pm 4$ & NS & $323 \pm 7$ & NS & $313 \pm 4$ & NS & $313 \pm 2$ \\
\hline Urea, $m M$ & $3.1 \pm 0.2$ & $<0.001$ & $14.3 \pm 0.9$ & $<0.001$ & $2.6 \pm 0.2$ & $<0.001$ & $3.7 \pm 0.3$ \\
\hline $\begin{array}{l}\text { Sodium, } \\
\text { meq/liter }\end{array}$ & $149 \pm 2$ & $<0.001$ & $153 \pm 3$ & NS & $148 \pm 2$ & NS & $150 \pm 2$ \\
\hline $\begin{array}{l}\text { Potassium, } \\
\text { meq/liter }\end{array}$ & $3.9 \pm 0.2$ & NS & $4.3 \pm 0.2$ & NS & $3.9 \pm 0.2$ & $<0.01$ & $4.4 \pm 0.3$ \\
\hline
\end{tabular}

Data are the means \pm SE. Abbreviation: NS, not significant $(P>0.05)$.

* Significance of the difference between first and second period, using paired comparisons.

¥ Significance of the difference in change between periods in group I compared to that in group II, using group comparison.

Collecting duct fluid (Table III). The osmolality of collecting duct urine from the exposed papilla was hyperosmotic during the initial period of study. In response to urea infusion, the mean osmolality of collecting duct fluid rose significantly from 686 to 1,047 mosmols $/ \mathrm{kg}$ $\mathrm{H}_{2} \mathrm{O}$ whereas there was no significant change in the control group. The concentration of both urea and nonurea solute in collecting duct urine also increased sig-

TABLE II

Right Kidney Function

\begin{tabular}{|c|c|c|c|c|c|c|c|}
\hline & \multirow{2}{*}{\multicolumn{3}{|c|}{$\begin{array}{c}\text { Group I, urea infusion }(n=10) \\
\text { Kidney wt } 0.293 \pm 0.011 \mathrm{~g}\end{array}$}} & \multirow[b]{3}{*}{$P \S$} & \multicolumn{3}{|c|}{ Group II, control $(n=7)^{*}$} \\
\hline & & & & & \multicolumn{3}{|c|}{ Kidney wt $0.275 \pm 0.007 \mathrm{~g}$} \\
\hline & First period & $P \ddagger$ & Second period & & First period & $P \ddagger$ & Second period \\
\hline $\begin{array}{l}\text { Urine flow, } \\
\qquad \mu l \min ^{-1} g k w^{-1}\end{array}$ & $4.85 \pm 0.53$ & NS & $5.31 \pm 0.81$ & NS & $4.18 \pm 0.37$ & $<0.05$ & $5.75 \pm 0.61$ \\
\hline GFR, $\mu l \min ^{-1} g k w^{-1}$ & $1,101 \pm 164$ & NS & $1,052 \pm 152$ & NS & $1,130 \pm 102$ & NS & $1,162 \pm 109$ \\
\hline $\begin{array}{l}\text { Osmolality, } \\
\quad \text { mosmols } / \mathrm{kg} \mathrm{H}_{2} \mathrm{O}\end{array}$ & $804 \pm 61$ & $<0.001$ & $1,277 \pm 107$ & $<0.005$ & $831 \pm 52$ & $<0.05$ & $975 \pm 46$ \\
\hline Irea, $m M$ & $121 \pm 21$ & $<0.001$ & $313 \pm 41$ & $<0.001$ & $126 \pm 17$ & NS & $134 \pm 14$ \\
\hline NUS, mosmols $/ \mathrm{kg} \mathrm{H}_{2} \mathrm{O}$ & $683 \pm 50$ & $<0.001$ & $964 \pm 66$ & $\mathrm{NS} \|$ & $706 \pm 41$ & $<0.05$ & $841 \pm 38$ \\
\hline $\mathrm{I} / \mathrm{P}$ inulin & $223 \pm 22$ & NS & $198 \pm 15$ & NS & $278 \pm 23$ & $<0.01$ & $210 \pm 19$ \\
\hline 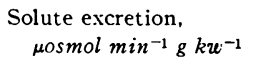 & $3.98 \pm 0.60$ & $<0.01$ & $6.96 \pm 1.23$ & NS & $3.53 \pm 0.49$ & $<0.025$ & $5.68 \pm 0.79$ \\
\hline FE total solute, $\%$ & $1.2 \pm 0.11$ & $<0.005$ & $2.0 \pm 0.12$ & NS & $1.0 \pm 0.10$ & $<0.025$ & $1.5 \pm 0.15$ \\
\hline FE sodium, $\%$ & $0.1 \pm 0.03$ & NS & $0.2 \pm 0.07$ & NS & $0.1 \pm 0.03$ & NS & $0.1 \pm 0.04$ \\
\hline
\end{tabular}

Data are the mean \pm SE. Abbreviations: FE, fractional excretion as percent of load; kw, kidney weight; NS, not significant $(P>0.05)$ NUS, nonurea solute; U/P inulin, urine-to-plasma inulin.

* One urinary sample was lost.

$¥$ Significance of the difference between first and second period, using paired comparison.

$\S$ Significance of the difference in change between periods in group I compared to that in group II, using group comparison.

II $0.05<P<0.06$. 
TABLE III

Composition of Fluid from Collecting Duct Tips

\begin{tabular}{|c|c|c|c|c|c|c|c|}
\hline & \multicolumn{3}{|c|}{ Group I, urea infusion $(n=10)$} & \multirow[b]{2}{*}{$P \ddagger$} & \multicolumn{3}{|c|}{ Group II, control $(n=8)$} \\
\hline & First period & $P^{*}$ & Second period & & First period & $P^{*}$ & Second period \\
\hline $\begin{array}{l}\text { Osmolality, } \\
\quad \text { mosmols } / \mathrm{kg} \mathrm{H}_{2} \mathrm{O}\end{array}$ & $686 \pm 52$ & $<0.001$ & $1,047 \pm 74$ & $<0.01$ & $712 \pm 67$ & NS & $795 \pm 49$ \\
\hline Urea, $m M$ & $105 \pm 16$ & $<0.001$ & $337 \pm 42$ & $<0.001$ & $112 \pm 20$ & NS & $133 \pm 10$ \\
\hline $\begin{array}{l}\text { NUS, } \\
\quad \text { mosmols } / k g H_{2} \mathrm{O}\end{array}$ & $581 \pm 43$ & $<0.05$ & $710 \pm 37$ & NS & $600 \pm 52$ & NS & $662 \pm 43$ \\
\hline $\mathrm{TF} / \mathrm{P}$ inulin & $122 \pm 14$ & NS & $111 \pm 11$ & NS & $162 \pm 14$ & NS & $131 \pm 17$ \\
\hline $\mathrm{TF} / \mathrm{P}$ osmolality & $2.24 \pm 0.16$ & $<0.001$ & $3.25 \pm 0.21$ & $<0.025$ & $2.28 \pm 0.21$ & NS & $2.54 \pm 0.17$ \\
\hline FE total solute, $\%$ & $2.4 \pm 0.38$ & $<0.025$ & $3.2 \pm 0.30$ & NS & $1.5 \pm 0.16$ & $<0.05$ & $2.2 \pm 0.28$ \\
\hline FE sodium, $\%$ & $0.4 \pm 0.08$ & NS & $0.4 \pm 0.13$ & NS & $0.3 \pm 0.05$ & NS & $0.4 \pm 0.11$ \\
\hline
\end{tabular}

Data are the mean $\pm \mathrm{SE}$. Abbreviations: FE, fractional excretion as percent of filtered load; NS, not significant $(\mathrm{P}>0.05)$; NUS, nonurea solute.

* Significance of the difference between first and second period, using paired comparisons.

‡ Significance of the difference in change between periods in group I compared to that in group II, using group comparison.

nificantly after urea infusion. Fractional excretion of total solute, water, and sodium was comparable in both groups of rats.

Descending limb fluid (Table IV).4 The concentra-

${ }^{4}$ For reasons previously discussed (13), we consider fluid obtained near the hairpin turn of Henle's loop to represent fluid from the end of the descending limb. tion of urea rose strikingly in loop of Henle fluid in the urea-infused rats, while changing only slightly in the control group (Fig. 1). Indeed, the infusion of urea to these protein-depleted rats restored the urea concentration of descending limb and collecting-duct fluids to values similar to those previously found for antidiuretic rats fed normal diets $(287 \mathrm{mM} \pm 32$ and $345 \mathrm{mM} \pm 42$ in de-

TABLE IV

Composition of Fluid from End-Descending Limb

\begin{tabular}{|c|c|c|c|c|c|c|c|}
\hline & \multicolumn{3}{|c|}{ Group I, urea infusion $(n=10)$} & \multirow[b]{2}{*}{$P \ddagger$} & \multicolumn{3}{|c|}{ Group II, control $(n=8)$} \\
\hline & First period & $P^{*}$ & Second period & & First period & $P^{*}$ & Second period \\
\hline $\begin{array}{l}\text { Osmolality, } \\
\quad \text { mosmols } / \mathrm{kg} \mathrm{H}_{2} \mathrm{O}\end{array}$ & $629 \pm 46$ & $<0.001$ & $1,052 \pm 88$ & $<0.025$ & $615 \pm 49$ & $<0.01$ & $792 \pm 39$ \\
\hline Urea, $m M$ & $82 \pm 16$ & $<0.005$ & $261 \pm 38$ & $<0.01$ & $89 \pm 16$ & $<0.025$ & $125 \pm 15$ \\
\hline Sodium, meq/liter & $245 \pm 19$ & $<0.001$ & $354 \pm 29$ & NS & $236 \pm 17$ & $<0.005$ & $316 \pm 13$ \\
\hline $\mathrm{TF} / \mathrm{P}$ inulin & $4.62 \pm 0.52$ & $<0.025$ & $6.41 \pm 0.72$ & $<0.025$ & $4.55 \pm 0.68$ & NS & $4.18 \pm 0.36$ \\
\hline $\mathrm{TF} / \mathrm{P}$ osmolality & $2.01 \pm 0.13$ & $<0.001$ & $3.25 \pm 0.25$ & $<0.025$ & $1.97 \pm 0.16$ & NS & $2.53 \pm 0.14$ \\
\hline $\mathrm{TF} / \mathrm{P}$ sodium & $1.64 \pm 0.12$ & $<0.001$ & $2.32 \pm 0.18$ & NS & $1.58 \pm 0.10$ & $<0.005$ & $2.11 \pm 0.10$ \\
\hline $\mathrm{TF} / \mathrm{P}$ urea & $28 \pm 7$ & NS & $20 \pm 4$ & NS & $38 \pm 8$ & NS & $37 \pm 6$ \\
\hline
\end{tabular}

Data are the mean \pm SE. Abbreviations: Same as in Table IV.

* Significance of the difference between first and second period, using paired comparisons.

‡ Significance of the difference in change between periods in group I compared to that in group II, using group comparison. 

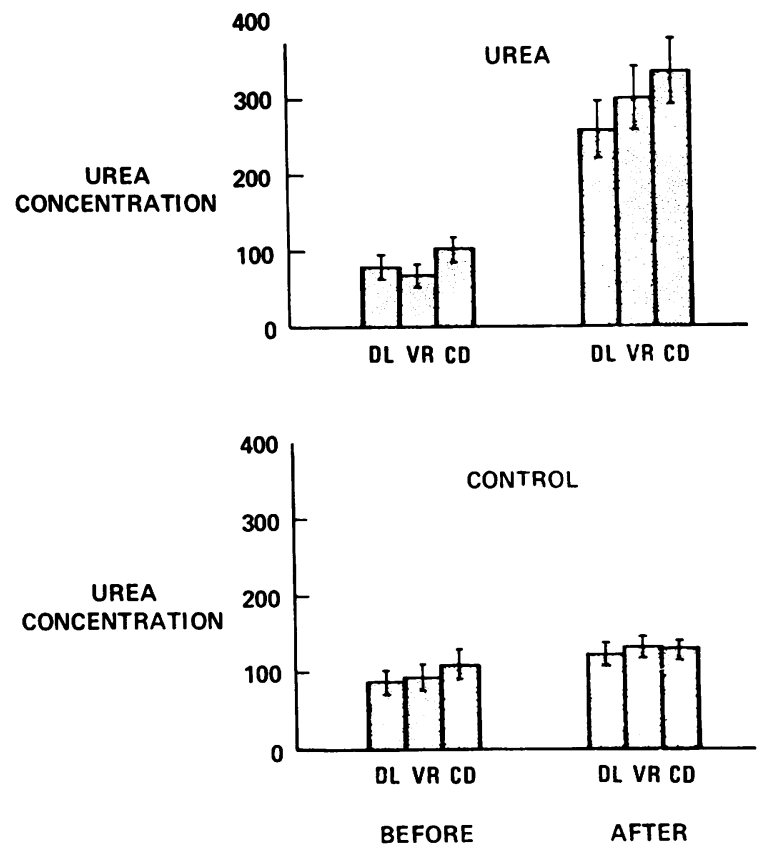

FIgURE 1 The concentration of urea $(\mathrm{mM})$ in vasa recta plasma (VR) and in fluid from descending limbs (DL) and collecting ducts (CD) during period one (before) and period two (after) in group I (urea) and group II (control) rats.

scending limb and collecting duct fluid (16), respectively, vs. $261 \mathrm{mM} \pm 38$ and $337 \mathrm{mM} \pm 42$ in the present study). The mean $\mathrm{TF} / \mathrm{P}$ urea in the control periods was not significantly different between the control and ureainfused animals. The variability in $T F / P$ ' urea reflects the very low concentrations of plasma urea in the control rats in both periods and in the urea group during period I. A small error in the analysis of plasma urea would result in a large change in the corresponding

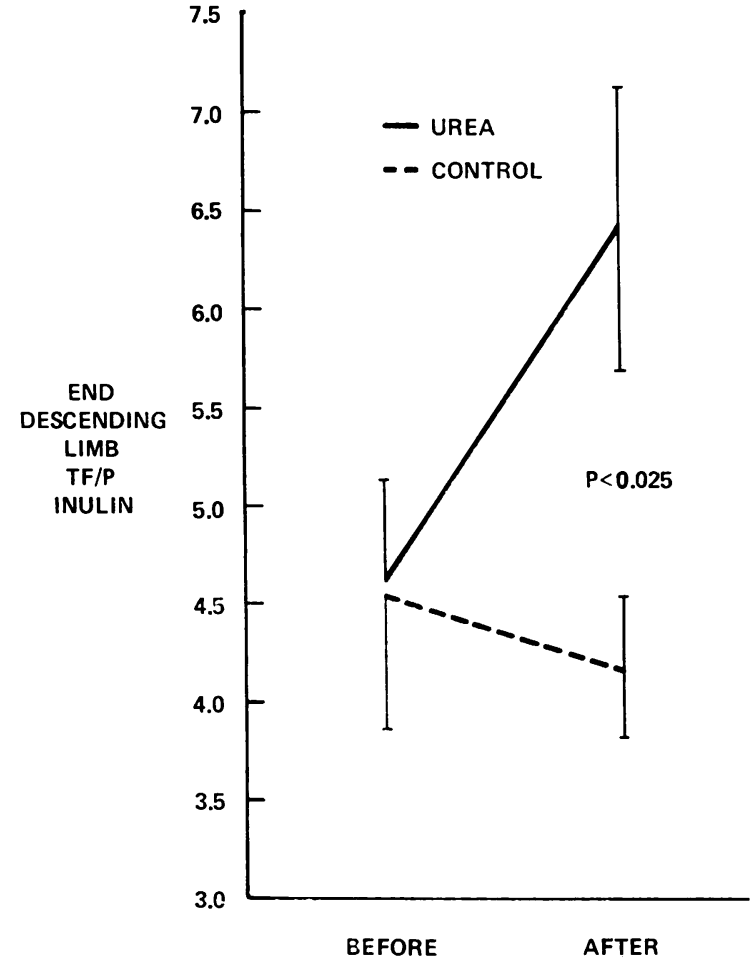

FIGURE $2 \mathrm{TF} / \mathrm{P}$ inulin of fluid at the end of the descending limb during period one (before) and period two (after) in group I (urea, solid line) and group II (control, dashed line). The $\mathrm{TF} / \mathrm{P}$ inulin increased significantly after urea infusion, but did not change significantly in the control animals.

$\mathrm{TF} / \mathrm{P}$ urea. Because the concentration of urea increased by a greater factor in the plasma than it did in the tubule fluid, the mean $\mathrm{TF} / \mathrm{P}$ urea was slightly but not significantly lower after urea infusion.

The increase in osmolality of fluid at the end of the descending limb after urea infusion (423 \pm 76 mosmols/

TABLE V

Composiiion of Plasma from Ascending Vasa Recta

\begin{tabular}{|c|c|c|c|c|c|c|c|}
\hline & \multicolumn{3}{|c|}{ Group I, urea infusion $(n=8)^{*}$} & \multirow[b]{2}{*}{$P \S$} & \multicolumn{3}{|c|}{ Group II, control $(n=8)$} \\
\hline & $\begin{array}{l}\text { First } \\
\text { period }\end{array}$ & $P \ddagger$ & $\begin{array}{l}\text { Second } \\
\text { period }\end{array}$ & & $\begin{array}{l}\text { First } \\
\text { period }\end{array}$ & $P \ddagger$ & $\begin{array}{l}\text { Second } \\
\text { period }\end{array}$ \\
\hline $\begin{array}{l}\text { Osmolality, } \\
\quad \text { mosmols } / \mathrm{kg} \mathrm{H}_{2} \mathrm{O}\end{array}$ & $705 \pm 62$ & $<0.005$ & $985 \pm 91$ & $\lambda \mathrm{S} \|$ & $706 \pm 54$ & $<0.05$ & $830 \pm 43$ \\
\hline Urea, $m M \uparrow$ & $71 \pm 15$ & $<0.001$ & $302 \pm 41$ & $<0.001$ & $95 \pm 17$ & $\mathrm{NS}$ & $134 \pm 14$ \\
\hline Sodium, meq/iiter & $266 \pm 24$ & Is & $280 \pm 27$ & NS & $276 \pm 21$ & $\mathrm{NS}$ & $309 \pm 13$ \\
\hline
\end{tabular}

Data are the mean \pm SE. Abbreviations: same as in Table IV.

${ }^{*} n=8$ rather than 10 because in two rats ascending vasa recta plasma not obtained in both periods. $\ddagger, \S$ Same as in Table II.

II $0.05<P<0.06$.

I Corrected for plasma water, assuming protein concentration of vasa recta plasma $=5 \mathrm{~g} / 100 \mathrm{ml}$. 
TABLE VI

Osmotic and Solute Concentration Differences between Descending Limb and Ascending Vasa Recta

\begin{tabular}{|c|c|c|c|c|c|c|}
\hline & \multicolumn{3}{|c|}{ Group I, urea infusion $(n=8) *$} & \multicolumn{3}{|c|}{ Group II, control $(n=8)$} \\
\hline & First period & Second period & $\Delta \ddagger$ & First period & Second period & $\Delta \ddagger$ \\
\hline $\begin{array}{l}\text { Osmolality }_{\mathrm{DL}}-\text { osmolality }_{\mathrm{AVR}} \text {, } \\
\quad \text { mosmols } / \mathrm{kg} \mathrm{H}_{2} \mathrm{O}\end{array}$ & $\begin{array}{c}-85 \pm 37 \\
0.05<P<0.06\end{array}$ & $\begin{array}{l}-9 \pm 45 \\
\mathrm{NS}\end{array}$ & $\begin{array}{l}76 \pm 39 \\
\mathrm{NS}\end{array}$ & $\begin{array}{l}-91 \pm 34 \\
P<0.05\end{array}$ & $\begin{array}{c}-38 \pm 41 \\
\mathrm{NS}\end{array}$ & $\begin{array}{c}53 \pm 41 \\
\text { NS }\end{array}$ \\
\hline$[\text { Urea }]_{\mathrm{DL}}-[\text { urea }]_{\mathrm{AvR}}, m M$ & $\begin{array}{l}14 \pm 17 \\
\mathrm{NS}\end{array}$ & $\begin{array}{l}-82 \pm 29 \\
P<0.05\end{array}$ & $\begin{array}{l}-96 \pm 33 \\
P<0.01\end{array}$ & $\begin{array}{l}-6 \pm 15 \\
\mathrm{NS}\end{array}$ & $\begin{array}{l}-9 \pm 4 \\
\mathrm{NS}\end{array}$ & $\begin{array}{c}-3 \pm 15 \\
\mathrm{NS}\end{array}$ \\
\hline$[\mathrm{Na}]_{\mathrm{DL}}-[\mathrm{Na}]_{\mathrm{AVR}}$, meq/liter & $\begin{array}{c}-27 \pm 20 \\
\mathrm{NS}\end{array}$ & $\begin{array}{c}57 \pm 26 \\
\mathrm{NS}\end{array}$ & $\begin{array}{c}84 \pm 25 \\
P<0.025\end{array}$ & $\begin{array}{c}-27 \pm 27 \\
\mathrm{NS}\end{array}$ & $\begin{array}{c}23 \pm 12 \\
\mathrm{NS}\end{array}$ & $\begin{array}{c}50 \pm 32 \\
\mathrm{NS}\end{array}$ \\
\hline
\end{tabular}

Data are mean \pm SE. Abbreviations: AVR, ascending vasa recta; DL, descending limb; NS, not significant $(P>0.05)$.

${ }^{*} n=8$ rather than 10 because in two rats ascending vasa recta plasma not obtained in both periods.

$\ddagger \Delta=$ second period minus first period.

Comparing the $\Delta$ between the first and second period in the urea infusion group with that between the first and second period in the control group, only the $\Delta$ 's for [urea $]_{\mathrm{DL}}-[\text { urea }]_{\mathrm{AVR}}$ were significantly different between the two groups $(P<0.01)$.

$\mathrm{kg} \mathrm{H}_{2} \mathrm{O}$ ) was significantly greater than in the control group $\left(177 \pm 46\right.$ mosmols $\left./ \mathrm{kg} \mathrm{H}_{2} \mathrm{O}\right)$. The $\mathrm{TF} / \mathrm{P}$ inulin of fluid at the end of the descending limb increased significantly after urea infusion from $4.62 \pm 0.52$ to $6.41 \pm$ 0.72 but did not change significantly in the control group (4.55 \pm 0.68 to $4.18 \pm 0.36$ ) (Fig. 2 ). There was a significant increase in $\mathrm{TF} / \mathrm{P}$ sodium of descending limb fluid in both groups; urea infusion had no differential effect.

Vasa recta plasma (Table $V$ ). The osmolality of vasa recta plasma increased significantly in both groups of rats, $280 \pm 56$ mosmols $/ \mathrm{kg} \mathrm{H}_{2} \mathrm{O}$ after urea infusion and $124 \pm 48$ mosmols $/ \mathrm{kg} \mathrm{H} \mathrm{H}_{2} \mathrm{O}$ in the control group. The concentration of urea rose strikingly after urea infusion, but the concentration of sodium did not change significantly.

Comparison of loop fluid and adjacent vasa recta plasma (Table $V I$ ). The differences in osmolality and concentration of sodium and urea between descending limb fluid and plasma of adjacent ascending vasa recta are shown in Table VI. In both groups during the first period, the osmolality of vasa recta plasma was slightly higher than that of adjacent descending limb fluid $(0.05$ $<P<0.06$ in group I and $P<0.05$ in group II), but the difference disappeared during the second period. After infusion of urea, the concentration of urea in vasa recta plasma was significantly higher than that in adjacent descending limb fluid.

The difference in sodium concentration between fluid in loops and adjacent vasa recta was not statistically significant in either period. However, after urea infusion, the sodium concentration difference changed significantly in a direction favoring diffusion of sodium out of loop of Henle fluid, while the change was not significant in the control group.

\section{DISCUSSION}

Control group. The osmolality of urine, loop fluid, and vasa recta plasma increased between the first and second periods in the control rats. Especially marked was the increase in osmolality of fluid from the descending limb $(+30 \%)$. Presumably the cause for the general rise in osmolality is related to those factors responsible for the increase in concentration of sodium in fluid in the descending limb from 236 to $316 \mathrm{meq} / \mathrm{liter}$. We have no ready explanation for this finding. However, the rats excreted a urine at the beginning of surgery significantly less concentrated (mean $=430 \pm 94$ mosmols/ $\mathrm{kg} \mathrm{H}_{2} \mathrm{O}$, unpublished data) than urine formed during the first period, $1 \mathrm{~h}$ after the $\mathrm{ADH}$-containing infusion was begun. The increase in concentration of sodium in descending limb fluid may represent in part a cumulative effect of A.DH, analogous to the effect of $\mathrm{ADH}$ in diuretic rats (19), or water deprivation in normal rats (20). We assume the factors responsible for the changes in the control animals were the same in the urea-infused rats, but cannot be certain.

Urea-infused group. The osmolality of urine from the right kidney increased after urea infusion by $59 \%$, reflecting an increase in the concentration of both urea and nonurea solute, in accord with published findings (1-6). We have previously observed $(13,16,21)$, as have others (22-24), that exposure of the papillary tip compromises the ability to elaborate a concentrated urine. (Compare urinary osmolality from right and left kidneys in Tables II and III.). However, it is noteworthy that after urea infusion, urinary osmolality increased by the same proportion in left and right kidneys and urinary concentrations of urea and nonurea solute from both 
sides were significantly increased. The osmolality and urea concentration of collecting tubule fluid after urea infusion were similar, respectively, to values previously found in normally fed rats (16). Thus, it seems reasonable to infer that changes in the composition of loop of Henle fluid and vasa recta plasma in the exposed papilla after urea infusion reflect qualitatively similar changes in the undisturbed contralateral kidney.

Loop of Henle fluid and vasa recta plasma. The experimental design permits a direct examination of the composition of papillary fluid compartments in vivo before and after enhancement of urinary concentration by urea administration to protein-depleted rats.

Although loop fluid and vasa recta plasma were initially hyperosmotic, the osmolality of each was substantially enhanced after urea infusion. The urea concentration in both vasa recta plasma and loop fluid was low in period I (Fig. 1), but after the urea infusion it was significantly higher in vasa recta plasma than in fluid in an adjacent descending limb (Table VI).

A striking finding after urea infusion was the increase in mean TF/P inulin in the end-descending limb from 4.62 to 6.41 , the latter value similar to that found in normal antidiuretic rats $(13,14,16)$ (Fig. 2). The site in the nephron in which water reabsorption was enhanced cannot be determined precisely because the juxtamedullary proximal tubule and its short pars recta (25) are inaccessible, but it is likely to be the descending limb. The reflection coefficient for urea of the isolated proximal tubule in vitro is approximately 0.7 (12), so that an increased urea concentration in the glomerular filtrate would, if anything, retard proximal tubule fluid reabsorption. The TF/P inulin at the end of the juxtamedullary proximal tubule can be estimated indirectly. Assuming (a) zero net transtubular flux of sodium across the descending limb (and pars recta in the outer medulla) and $(b) \mathrm{TF} / \mathrm{P} \mathrm{Na}=1.0$ in the juxtamedullary proximal tubule at the corticomedullary junction, the TF/P inulin at that point can be calculated by dividing end-descending limb $\mathrm{TF} / \mathrm{P}$ inulin by end-descending limb $\mathrm{TF} / \mathrm{P} \mathrm{Na}$ $(16,19)$. Computed in that manner, the TF/ $\mathrm{P}$ inulin in the juxtamedullary proximal tubule at the corticomedullary junction was $2.85 \pm 0.28$ before and $2.85 \pm 0.38$ after infusion of urea. Hence, we infer that the increase in $\mathrm{TF} / \mathrm{P}$ inulin after urea infusion was due to increased water extraction from the descending limb.

Role of urea in the urinary concentrating mechanism. Several investigations have focused upon the mechanism by which urea increases urinary osmolality (26-28). Berliner, Levinsky, Davidson, and Eden (26) proposed that urea supplied by passive diffusion from medullary collecting duct urine is maintained at a high concentration in the medullary interstitium by countercurrent exchange with Henle's loops and vasa recta. As a re- sult the high urinary concentration of urea adds to total urinary osmolality and is osmotically balanced across the collecting duct by interstitial urea rather than sodium chloride.

Recently another mechanism has been postulated for urea enhancement of urinary osmolality $(9,10)$. Stephenson (9) proposed that inner medullary hypertonicity is achieved by either an active transport mode or a passive mode. In both modes, solute $(\mathrm{NaCl}$ reabsorbed from the thin ascending limb and urea reabsorbed from the collecting duct) enters the vascular core (vasa recta and medullary interstitium) and extracts water from the descending limb, thereby increasing its solute concentration. The distinction between the two modes lies in the $\mathrm{NaCl}$ reabsorptive process in the thin ascending limb. In the active transport mode $\mathrm{Na}^{+}$is actively reabsorbed from the thin ascending limb, a proposal identical to that of Kuhn and Ramel (29) and reflecting Kuhn's original idea (30) that Henle's loop is the site of the energy requiring process by which water and solute are separated ("single effect"). In the passive mode, extraction of water from the descending limb elevates the $\mathrm{Na}^{+}$concentration of fluid delivered into the thin ascending limb above that in the vascular core so that a concentration difference is established for the passive reabsorption of $\mathrm{Na}^{+}$from the thin ascending limb by diffusion down its electrochemical gradient. One difference between active and passive modes, therefore, is that the greater the extent to which solute is secreted into the descending limb (solute recycling) rather than water extracted from it, the more difficult it is for a passive mode alone to generate the necessary driving force for $\mathrm{Na}^{+}$reabsorption from the thin ascending limb. For example, since the contents of the descending limb and medullary interstitium are in osmotic equilibrium, or very close thereto (31-34, Table VI), as more urea diffuses into the descending limb from the interstitium, and lessens the difference in urea concentration between the two compartments, the difference by which the sodium concentration in loop fluid exceeds that in the interstitium must necessarily be diminished.

Kokko and Rector (10) proposed in their passive model that fluid in the descending limb becomes concentrated almost exclusively (96\%) by water extraction owing to the high medullary interstitial urea concentration, and that hypertonicity of the inner medulla is maintained in a way similar to Stephenson's passive mode. In both passive models the energy required for medullary hypertonicity is supplied by active $\mathrm{Na}^{+}$reabsorption by the urea-impermeable thick ascending limb in the outer medulla and cortex, which results in a high urea concentration in collecting tubule fluid reaching the inner medulla $(9,10)$. It now seems clear that chloride, not sodium, is the principal ion actively transported out of 
the thick ascending limb $(35,36)$, but presumably whether sodium or chloride is actively transported is of little consequence to the theoretical models.

Our finding of enhanced water reabsorption in the descending limb after urea infusion confirms an important prediction of the passive models for the concentrating mechanism in vivo. To ascertain whether the increased water extraction led to an enhanced driving force favoring $\mathrm{NaCl}$ reabsorption from the thin ascending limb, we compared the composition of descending limb fluid and adjacent vasa recta plasma in the first and second periods in experimental and control animals (Table VI). In neither period was the difference in $\mathrm{Na}^{+}$ concentration between descending limb fluid and vasa recta plasma significant, although the change from first to second period was statistically significant and in a direction predicted by the passive models. The gradient for $\mathrm{Na}^{+}$diffusion is much less than that suggested by Kokko and Rector (see Fig. 2 in reference 10), but they have stated (10) that the absence of $\mathrm{NaCl}$ gradients at the bend of the loop does not necessarily negate their model because given the right combination of permeability characteristics and flow rates, a sufficiently hypoosmotic tubule fluid could be generated as fluid moves up the thin ascending limb into a region of lower interstitial salt concentration.

The high concentration of urea in fluid at the end of the descending limb after urea infusion (mean $=261$ $\mathrm{mM}$ ) presents two difficulties for a completely passive concentrating mechanism, one concerning the concentrating process in the descending limb and the other regarding the diluting process in the ascending limb. Calculations of the percentage of filtered urea remaining in fluid at the end of the descending limb ( $[\mathrm{TF} / \mathrm{P}$ urea $] /[\mathrm{TF} / \mathrm{P}$ inulin $]) \times 100$ reveal values consistently greater than $100 \%$, indicating net urea addition (secretion). In the first period the percentages remaining were $930 \% \pm 290 \% \mathrm{SE}$, control group, and $650 \% \pm 180 \%$, urea group (difference not statistically significant). In the second period the percentage remaining did not change significantly in control rats, $910 \% \pm 150 \%$. Although it declined to $300 \% \pm 50 \%$ after urea infusion, because the urea concentration increased by a greater factor in the plasma than in the tubule fluid, the change in percentage of filtered urea remaining was not statistically significant. The precise values are subject to some analytic uncertainty, especially in those periods where the plasma urea concentration was low, but it is clear that there was a large component of urea secretion in the juxtamedullary nephron up to the hairpin turn. Presuming the absence of urea secretion into the juxtamedullary proximal tubule, the most likely site of urea secretion is the descending limb.

The first difficulty posed by urea secretion for the passive models is: how can urea simultaneously extract water from the descending limb and be secreted into the descending limb? As indicated in the Appendix, a likely answer stems from the relative permeabilities of the descending limb to water and urea and the progressive increase in urea concentration in the inner medulla. We suggest the processes of water extraction and urea secretion are to a large degree spatially separated within the descending limb, water extraction occurring primarily in the initial half, and transtubular urea entry primarily in the distal half. This need not require varying permeability characteristics along the descending limb, but simply reflects the fact that water is reabsorbed by the descending limb at a faster rate than urea enters (see Appendix).

The second difficulty created by the high urea concentration in end-descending limb fluid with regard to the passive models is the implication that fluid issuing from the juxtamedullary thick ascending limb is hyperosmotic. It is essential to the passive models that a difference in urea concentration exist between medullary interstitium and thin ascending limb fluid favoring urea diffusion into the thin ascending limb throughout the entire inner medulla. Since both thin (37-39) and thick ascending limbs $(35,36)$ are impermeable to water and the thick ascending limb is impermeable to urea (40), it follows from the assumption of a gradient favoring urea entry into the thin ascending limb that the concentration of urea progressively increases as the tubule fluid ascends within the thin ascending limb and is maintained at its highest concentration throughout the thick ascending limb. Thus the concentration of urea in fluid at the end of the descending limb, according to the model, sets a lower limit for the concentration of urea in fluid leaving the juxtamedullary thick ascending limb in the cortex. Presumably other solutes are present in fluid in the thick ascending limb, too, notably $\mathrm{NaCl}$ (41). It is likely, therefore, that the total osmolality of fluid emerging from the juxtamedullary thick ascending limb in the cortex would exceed cortical interstitial osmolality, i.e., the fluid would not be hypo-osmotic but hyperosmotic. Indeed, this possibility is implicit in Kokko and Rector's original description (Fig. 2 in reference 10). However, an essential requirement of the countercurrent multiplier is that fluid leaving Henle's ascending limb be significantly hypo-osmotic to that entering the descending limb, i.e. to the cortical interstitium, as has been found to be the case for fluid emerging from the superficial thick ascending limb (42). Kokko has stated (personal communication) that hyperosmotic fluid may issue into the juxtamedullary distal tubule as long as the net result is the delivery of a hypo-osmotic fluid into distal tubules as a whole. 
In other words, dissipation of the osmotic gradient owing to net removal of solute in excess of water from the medulla by juxtamedullary nephrons is offset by the counter-balancing action of the delivery of hypoosmotic fluid from the medulla by the superficial nephrons, since they outnumber juxtamedullary nephrons by three or four to one in the rat.

On the other hand, if fluid issuing from the juxtamedullary thick ascending limb is hypo-osmotic to the cortical interstitium, urea reabsorption must occur in the ascending limb, presumably the urea-permeable thin segment. Since $\mathrm{NaCl}$ is the other principal solute present, to the extent that urea diffuses out of the thin ascending limb, continued reabsorption of $\mathrm{NaCl}$ in that segment can no longer be accounted for by the proposed passive mechanism.

The present findings do suggest that urea contributes to the inner medullary concentrating mechanism by extracting water from the descending limb, elevating the concentration of $\mathrm{NaCl}$ in fluid entering the thin ascending limb, and reducing net back leak of $\mathrm{NaCl}$ from interstitium to tubule lumen (9). Thus urea may enhance net reabsorption of $\mathrm{NaCl}$ from the thin ascending limb by the simultaneous operation of both active transport and passive modes (9).

To summarize, enhanced urinary osmolality in protein-depleted rats infused with urea is attended by: $(a)$ increased papillary hypertonicity; $(b)$ increased urea concentration in all papillary structures; and $(c)$ increased water extraction from the descending limb. Moreover, a small but statistically significant shift in the transtubular difference in sodium concentration was observed favoring the efflux of salt from the thin ascending limb and minimizing back leak. The results provide strong support for the idea that urea extracts water from the descending limb, but in our view they are difficult to reconcile with a purely passive inner medullary concentrating mechanism, suggesting instead that solute $(\mathrm{NaCl})$ reabsorption from the thin ascending limb occurs, at least in part, by active transport.

\section{APPENDIX}

The purpose of this Appendix is to examine whether urea in the medullary interstitium can contribute to the osmotic driving force for extracting water from the descending limb of Henle (DLH) and at the same time enter the DLH in substantial quantities over its length. The results of the determination are affirmative and indicate that the processes of water extraction and urea entry occur to a large extent at spatially separate sites in the DLH. The numerical values, though close to data obtained in vivo, are intended as a qualitative, not a quantitative representation.

The model chosen is a semi-flow-through system in which exterior conditions are forced to represent linear concen- tration profiles for $\mathrm{NaCl}$ and urea in the medullary interstitium.

At any given point, $x$, along the length of the $\mathrm{DLH}$, the equations governing transtubular fluxes of solvent and solutes are provided by irreversible thermodynamics (43), and are:

$$
J_{v}=L_{p} \cdot S_{p}\left(\Delta p-\Sigma_{\imath} \sigma_{\imath} \Delta \pi_{\mathfrak{i}}\right) \text { for the solvent, }
$$

and

$J_{i}=P_{i} \cdot S_{p} \Delta C_{i}+\bar{C}_{i}\left(1-\sigma_{i}\right) J_{v}$ for the solutes $i$,

where $J_{v}$ is the transmembrane water flux, $J_{i}$ is the transmembrane flux of solute $i, L_{p}$ is the membrane hydraulic permeability, $P_{i}$ is the membrane permeability to solute $i$, $\sigma_{i}$ is the reflection coefficient of the membrane to solute $i$, $\pi_{i}$ is the osmotic pressure due to solute $i, \bar{C}_{i}$ is the log mean concentration of solute $i, S_{p}$ is the surface area per unit length of the membrane, and $p$ is the hydraulic pressure.

The system is governed by a set of mass balance equations for the rates of change of mass flow down the DLH of solvent and solutes. For the purpose of simplicity, only equations for water and urea are considered here, although the interior and exterior $\mathrm{NaCl}$ concentrations affect the former. An equation for $\mathrm{NaCl}$ is not coupled to the other two as it is assumed that there is no movement of $\mathrm{NaCl}$ across the membranes (11).

The differential mass balance equations are:

$$
\frac{\mathrm{d} Q}{\mathrm{~d} x}=-J_{v} \text { for volumetric flow rate, }
$$

where

$Q=$ volumetric flow rate, $J_{v}=$ water flux out of the DLH lumen, and $x=$ length down the DLH.

$$
\frac{\mathrm{d}(C Q)}{\mathrm{d} x}=J_{u} \text { for urea mass flow rate, }
$$

where $C=$ concentration of urea in the DLH lumen and $J_{u}=$ urea flux into the DLH lumen.

Eq. 4 can be expanded to

$$
C \frac{\mathrm{d} Q}{\mathrm{~d} x}+Q \frac{\mathrm{d} C}{\mathrm{~d} x}=J_{u}
$$

and from Eq. 3 we get

$$
\frac{\mathrm{d} C}{\mathrm{~d} x}=\frac{1}{Q}\left(J_{u}+C J_{v}\right) .
$$

The two terms on the right side represent the increase in urea concentration due to urea entry and water extraction. Eqs. 3 and 5 represent a pair of coupled first-order nonlinear differential equations, since $J_{u}$ and $J_{v}$ are functions of $C$.

The expression for $J_{v}$ is simplified by consideration of only the osmotic term (the hydraulic pressure gradient can be safely assumed to be negligible across the DLH in vivo). The second term (solvent drag) in the expression for the urea flux, $J_{u}$, was also assumed negligible to the first order and this was confirmed a posteriori. 
The pair of equations were solved simultaneously using Runge-Kutta-Merson numerical scheme for the following conditions: flow rate entering DLH, $9 \mathrm{nl} / \mathrm{min}$; osmolality of $\mathrm{NaCl}$ entering the tubule, $300 \mathrm{mosmol} / \mathrm{kg} \mathrm{H} \mathrm{H}_{2} \mathrm{O}$; osmolality of urea entering the tubule, 0 mosmols $/ \mathrm{kg} \mathrm{H}_{2} \mathrm{O}$; external urea concentration, varying from 0 to 300 mosmols/ $\mathrm{kg} \mathrm{H}_{2} \mathrm{O}$ linearly along the DLH length; external $\mathrm{NaCl}$ concentration, varying from 300 to 700 mosmols $/ \mathrm{kg} \mathrm{H}_{2} \mathrm{O}$ linearly along the DLH length; length of DLH, $5 \mathrm{~mm}$; $P_{\text {NaCl, }}$ assumed 0 to consider only the effect of urea entry; $\sigma_{\text {urea }}, 0.95 ; \sigma_{\mathrm{NaCl}}, 0.96$; surface area to length of DLH ratio, $6 \times 10^{-6} \mathrm{~cm}$.

The equations were solved for two urea permeabilities reported in the literature $(12,37)$. For $P_{\text {urea }}=1.5 \times 10^{-5}$ $\mathrm{cm} / \mathrm{s}(12)$, the results were as follows:

\begin{tabular}{lccc}
\hline $\begin{array}{c}\text { Length } \\
\text { along } \\
\text { DLH }\end{array}$ & $\begin{array}{c}\text { Flow } \\
\text { rate in } \\
\text { DLH }\end{array}$ & $\begin{array}{c}\text { Urea } \\
\text { concen- } \\
\text { tration }\end{array}$ & $\begin{array}{c}\text { Urea mass } \\
\text { flow rate }\end{array}$ \\
\hline$m m$ & nl/min & $m M$ & mol $\times 10^{-11} / \min$ \\
0 & 9 & 0 & 0 \\
0.5 & 7.6 & 0.5 & 0.42 \\
1.0 & 6.3 & 2.6 & 1.68 \\
1.5 & 5.4 & 6.7 & 3.60 \\
2.0 & 4.8 & 13.0 & 6.18 \\
2.5 & 4.3 & 21.9 & 9.42 \\
3.0 & 3.9 & 33.5 & 13.2 \\
3.5 & 3.6 & 47.9 & 17.4 \\
4.0 & 3.4 & 64.9 & 22.0 \\
4.5 & 3.2 & 86.6 & 25.9 \\
5.0 & 3.0 & 106.4 & 32.2 \\
\hline
\end{tabular}

We see that there is a threefold drop in flow rate from $9 \mathrm{nl} / \mathrm{min}$ to $3 \mathrm{nl} / \mathrm{min}$, with most of the drop occurring in the first half of the DLH. Urea entry, on the other hand, takes place in increasing quantities as a function of distance, and very little urea enters over the early portion of the descending limb. Urea concentration therefore remains low in the early portion of the DLH, but rises sharply later on, due both to entry of urea and additional water extraction.

Under these conditions over the earliest sections of the DLH, e.g. the first millimeter, the lumenal fluid tends to equilibrate by water extraction almost exclusively. It is reasonable, then, that Kokko should have found this to be the case in vitro, since only small segments of DLH (approximately 1-2.8 mm) were perfused $(11,12)$. Moreover in the in vitro studies, the bath was made uniformly hyperosmolar to the perfusate by addition of solute (urea, or urea and salt) $(11,12)$. Thus there was a large osmotic gradient for water movement. In vivo, fluid in each successive segment of the DLH, as it enters a deeper stratum of the medulla, encounters only a minute osmotic driving force if the contents inside are already close to osmotic equilibrium. Thus a large hydraulic permeability of a tubular membrane does not imply dominance of water extraction over solute entry, especially if, as a result of this permeability, the osmotic gradients are very small over all but the earliest portion of the tubule.
When $P_{\text {ures }}=15 \times 10^{-5} \mathrm{~cm} / \mathrm{s}$ (37), the results were quantitatively different, but qualitatively similar:

\begin{tabular}{cccc}
\hline $\begin{array}{c}\text { Length } \\
\text { along } \\
\text { DLH }\end{array}$ & $\begin{array}{c}\text { Flow } \\
\text { rate in } \\
\text { DLH }\end{array}$ & $\begin{array}{c}\text { Urea } \\
\text { concen- } \\
\text { tration }\end{array}$ & $\begin{array}{c}\text { Urea mass } \\
\text { flow rate }\end{array}$ \\
\hline$m m$ & $n l / m i n$ & $m M$ & mol $\times 10^{-11} /$ min \\
0 & 9 & 0 & 0 \\
0.5 & 7.7 & 5 & 3.96 \\
1.0 & 6.5 & 20 & 13.2 \\
1.5 & 5.8 & 43.7 & 25.4 \\
2.0 & 5.3 & 72.5 & 38.6 \\
2.5 & 4.9 & 104 & 51.6 \\
3.0 & 4.6 & 138 & 63.8 \\
3.5 & 4.3 & 172 & 75.0 \\
4.0 & 4.1 & 207 & 85.2 \\
4.5 & 3.9 & 241 & 94.2 \\
5.0 & 3.7 & 274 & 102 \\
\hline
\end{tabular}

Note that in either case $\mathrm{NaCl}$ was not allowed to pass into the DLH lumen from the exterior. Releasing this constraint would further increase solute entry over the length of the DLH as opposed to water extraction.

In summary, although both water abstraction and solute entry occur over the entire length of DLH, the decrease in flow rate in the DLH occurs principally over its initial portion, whereas solute entry, and particularly solute concentration of fluid in the lumen, rise largely over the later portion. The effects are more separated spatially for smaller solute permeability and larger hydraulic permeability. In this manner urea in the medullary interstitium acts to extract water from the DLH and also diffuses into the DLH.

\section{ACKNOWLEDGMENTS}

The authors are grateful for the technical assistance of Ms. Mary Fisher, the secretarial assistance of Ms. Marjorie Iburg, and the helpful advice of Frank Lacy, Dr. Roy Maffly and Dr. Channing Robertson.

This work was supported by U. S. Public Health Service Research Grant, HL 14784 from the National Heart and Lung Institute, U. S. Public Health Service Special Research Fellowship 2 F03 AM 50698 from the Institute of Arthritis and Metabolic Diseases (Dr. Pennell), U. S. Public Health Service Research Career Development Award 7-KO4-HL 42685 from the National Heart and Lung Institute (Dr. Jamison), and American Heart Association grant-in-aid 72821 .

\section{REFERENCES}

1. Gamble, J. J., C. F. McKhann, A. M. Butler, and E. Tuthill. 1934. An economy of water in renal function referable to urea. Am. J. Physiol. 109: 139-154.

2. Epstein, F. H., C. R. Kleeman, S. Pursel, and A. Hendrikx. 1957. The effect of feeding protein and urea on the renal concentrating process. J. Clin. Invest. 36: 635-641.

3. Hendrikx, A., and F. H. Epstein. 1958. Effect of feeding protein and urea on renal concentrating ability in the rat. Am. J. Physiol. $195:$ 539-542.

4. Levinsky, N. C., and R. W. Berliner. 1959. The role of urea in the urine concentrating mechanism. J. Clin. Invest. 38: 741-748. 
5. Crawford, J. D., A. P. Doyle, and J. M. Probst. 1959. Service of urea in renal water conservation. Am. J. Physiol. 196: 545-548.

6. Bray, G. A., and A. S. Preston. 1961. Effect of urea on urine concentration in the rat. J. Clin. Invest. 40: 1952-1960.

7. Klahr, S., and G. A. O. Alleyne. 1973. Effects of chronic protein-calorie malnutrition on the kidney. Kidney Int. 3: 129-141.

8. Schmidt-Nielsen, B., and D. W. S. Kerr. 1970. Urea and the Kidney. Excerpta Medica Foundation, Publishers, Amsterdam.

9. Stephenson, J. L. 1972. Concentration of urine in a central core model of the renal counterflow system. Kidney Int. 2: 85-94.

10. Kokko, J. P., and F. C. Rector, Jr. 1972. Countercurrent multiplication system without active transport in inner medulla. Kidney Int. 2: 214-223.

11. Kokko, J. P. 1970. Sodium chloride and water transport in the descending limb of Henle. J. Clin. Invest. 49: 1838-1846.

12. Kokko, J. P. 1972. Urea transport in the proximal tubule and the descending limb of Henle. J. Clin. Invest. 51: 1999-2008.

13. Jamison, R. L. 1970. Micropuncture study of superficial and juxtamedullary nephrons in the rat. $\mathrm{Am}$. J. Physiol. 218: 46-55.

14. Jamison, R. L., and F. B. Lacy. 1971. Effect of saline infusion on superficial and juxtamedullary nephrons in the rat. Am. J. Physiol. 221: 690-697.

15. Jamison, R. L. 1968. Micropuncture study of segments of the thin loop of Henle in the rat. Am. J. Physiol. 215: 236-242.

16. Pennell, J. P., F. B. Lacy, and R. L. Jamison. 1974. An in vivo study of the concentrating process in the descending limb of Henle's loop. Kidney Int. 5 : 337-347.

17. Henry, R. J. 1964. Clinical Chemistry. Harper \& Row, Publishers, New York. 179-186.

18. Snedecor, G. W. 1956. Statistical Methods. Iowa State University Press, Ames.

19. Jamison, R. L., J. Buerkert, and F. Lacy. 1973. A micropuncture study of Henle's thin loop in Brattleboro rats. Am. J. Physiol. 224: 180-185.

20. Valtin, H. 1966. Sequestration of urea and nonurea solutes in renal tissues of rats with hereditary hypothalamic diabetes insipidus: effect of vasopressin and dehydration on the countercurrent mechanism. J. Clin. Invest. 45: 337-345.

21. Jamison, R. L., J. Buerkert, and F. Lacy. 1971. A micropuncture study of collecting tubule function in rats with hereditary diabetes insipidus. J. Clin. Invest. 50: 2444-2452.

22. Gertz, K. H., B. Schmidt-Nielsen, and H. D. Pagel. 1966. Exchange of water, urea, and salt between the mammalian renal papilla and the surrounding urine. Fed. Proc. 25: 327. (Abstr.)

23. Schmidt-Nielsen, B. 1969. The renal excretion of nitrogen containing metabolites. Comparative physiology of urea excretion. In Progress in Nephrology. G. Peters and F. Roch-Ramel, editors. Springer-Verlag, Berlin. 1-11.

24. Schutz, W., and J. Schnermann. 1972. Pelvic urine composition as a determinant of inner medullary solute concentration and urine osmolality. Pfluegers Arch. Eur. J. Physiol. 334: 154-166.
25. Baines, A. D., and C. deRouffignac. 1969. Functional heterogeneity of nephrons. II. Filtration rates, intraluminal flow velocities, and fractional water reabsorption. Pfluegers Arch. Eur. J. Physiol. 308: 260-276.

26. Berliner, R. W., N. G. Levinsky, D. G. Davidson, and M. Eden. 1958. Dilution and concentration of the urine and the action of antidiuretic hormone. Am. J. Med. 24: 730-744.

27. Schmidt-Nielsen, B., and R. R. Robinson. 1970. Contribution of urea to urinary concentrating ability in the dog. Am. J. Physiol. 218: 1363-1369.

28. Schmidt-Nielsen, B., and D. W. S. Kerr. 1970. Urea and the Kidney. Excerpta Medica Foundation, Publishers, Amsterdam. 159, 175-216, 283-416, 430.

29. Kuhn, W., and A. Ramel. 1959. Aktiver Salztransport als möglicher (und wahrscheinlicher) Einzeleffekt bei der Harnkenzentrierung in der Niere. Helv. Chim. Acta. 42 : 628-660.

30. Kuhn, W., and K. Ryffel. 1942. Herstellung konzentrierter Losungen aus verdunnten durch blosse Membranwirkung. Ein Modellversuch zur Funktion der Niere. Hoppe-Seyler's Z. Physiol. Chem. 276: 145-178.

31. Gottschalk, C. W., and M. Mylle. 1959. Micropuncture study of the mammalian urinary concentrating mechanism: evidence for the countercurrent hypothesis. $\mathrm{Am}$. J. Physiol. 196: 927-936.

32. Windhager, E. E. 1964. Electrophysiological study of renal papilla of golden hamsters. Am. J. Physiol. 206: 694-700.

33. Marsh, D. J., and Solomon, S. 1965. Analysis of electrolyte movement in thin Henle's loops of hamster papilla. Am. J. Physiol. 208: 1119-1128.

34. Jamison, R. L., C. M. Bennett, and R. W. Berliner. 1967. Countercurrent multiplication by the thin loops of Henle. Am. J. Physiol. 212: 357-366.

35. Burg, M. B., and N. Green. 1973. Function of the thick ascending limb of Henle's loop. Am. J. Physiol. 224: 659-668.

36. Rocha, A. S., and J. P. Kokko. 1973. Sodium chloride and water transport in the medullary thick ascending limb of Henle. J. Clin. Invest. 52: 612-623.

37. Imai, M., and J. Kokko. 1974. Sodium chloride, urea, and water transport in the thin ascending limb of Henle. Generation of osmotic gradients by passive diffusion of solutes. J. Clin. Invest. 53: 393-402.

38. Marsh, D. J. 1970. Solute and water flows in thin limbs of Henle's loop in the hamster kidney. Am. J. Physiol. 218: 824-831.

39. Morgan, T., and R. W. Berliner. 1968. Permeability of the loop of Henle, vasa recta, and collecting duct to water, urea, and sodium. Am. J. Physiol. 215: 108-115.

40. Kokko, J. P. 1974. Membrane characteristics governing salt and water transport in the loop of Henle. Fed. Proc. 33 : 25-30.

41. Malnic, G., R. M. Klose, and G. Giebisch. 1966. Micropuncture study of distal tubular potassium and sodium transport in rat nephrons. Am. J. Physiol. 211: 529-547.

42. Morgan, T. 1972. Permeability of the thin limbs of the loop of Henle. H. Villarreal, editor. Karger AG., S., Basel. 2: 105-111.

43. Katchalsky, A., and P. Curran. Nonequilibrium Thermodynamics in Biophysics. 1967. Harvard University Press, Cambridge. 